\title{
Pricing And Long-Run Performance Of The Venture-Backed And Nonventure-Backed IPOS
}

Arvin Ghosh (E-mail: ghosha@wpunj.edu), William Paterson University

\begin{abstract}
Initial Public Offerings (IPOs) were the most prevalent form to raise capital by firms wanting to go public during the last decade $(1990$ - 2000) in the United State. There were thousands of firms that went public for the first time, mostly in the technology-heavy NASDAQ stock market. Along with the regular IPOs came the IPOs backed by venture capitalists, who specialize in financing promising startup companies and bringing them public. As one-third of the IPOs were backed by venture capitalists during 1990 - 2000, our purpose here is to examine the pricing and long-run performance of the venture-backed and nonventure-backed IPOs that were issued in the NYSE and NASDAQ stock market during the period covered by our study. We have found, among others, that the venture-backed IPOs performed much better as compared to the nonventure-backed IPOs. The returns of the former were consistently higher than the latter during $1900-2000$. Also, the price returns as well as the operating ratios and the growth of cash flows, were higher both in the NYSE and NASDAQ market. The regression equations also confirmed closer association with the independent variables belonging to the IPOs backed by venture capital than the non-venture capital.
\end{abstract}

\subsection{Introduction}

nitial public offerings (IPOs) were the most prevalent form of securities issuance to raise capital firms wanting to go public during the last decade (1990-2000) in the United States. The IPO phenomenon got a tremendous boost during the late 1990s by the popularity of the Internet stocks. Unfortunately, with the stock market downturn that taken place after the Spring of 2000, many of these stocks had succumbed to the market pressure and had gone out of the market. Many well-established companies in the United States had also taken resort to the IPO market that are still in business and some are, in fact, thriving. Although technology-heavy NASDAQ stock market had the largest number of IPO firms, the New York Stock Exchange (NYSE) also had its share of the IPOs which were not insignificant in number at all.

Along with the regular IPOs came the IPOs backed by venture capitalists, who specialized in financing promising startup companies and bringing them public. They were the ones which substantially provided muchneeded capital for the new public firms that were less depended upon solely public-supported capital. It is to be noted here that since 1990, one out of every three IPOs was backed by venture capital, as data compiled by the Securities Data Company of Thomson Financial disclosed.

In this paper, we have addressed the question whether venture-backed IPOs perform better than the nonventure-backed IPOs. For that, we have taken the time period 1990-2000-- a period of exceptional IPO growth, venture-backed and nonventure-backed alike. We have taken a sample of IPO firms, selected randomly both from the NYSE and NASDAQ stock market. For the regression analysis to explore the causal relationship, however, we have taken the data of the NYSE IPOs only, because these firms were better financed and adhered to higher standards.

Readers with comments or questions are encouraged to contact the author via email. 


\subsection{Literature Review and Data Source}

The underpricing of the IPOs in the short-run and their underperformance in the long-run are the general conclusions of most of the IPO studies regarding pricing and performance. The seminal articles by Jay Ritter (1991), and Longhran \& Ritter (1995), as well as the review article by Ritter and Welch (2002) had discussed in detail these underpricing and long-run underperformance phenomena, particularly in the light of different econometric methodology and differing sample periods. Ritter and Welch also raised the question that nonrational explanations and agency conflicts might play an important part, especially during the so-called 'bubble' period of late '90s. They have also adhered to the view that share allocation and subsequent ownership of stocks should also be considered in future research of IPO pricing.

The contrasting evidence was advanced by Brav and Gompers (1997 in this regard. They had investigated the long-run underperformance of the IPO firms after partitioning them into venture-backed and nonventure-backed IPOs issued during the period of 1975-1992. They had found that venture-backed IPOs outperformed nonventurebacked IPOs using equal-weighted return. Also, value-weighting had significantly reduced performance differences and had substantially reduced underperformance for nonventure-backed IPOs in their sample. In tests using comparable benchmarks and the Fama-French (1993) three-factor asset pricing model relating to market return, size and book-to-market ratio, they also found that venture-backed IPOs did not significantly underperformed while the smallest nonventure-backed IPOs did.

Brav and Gompers had found that underperformance in the nonventure-backed sample was driven primarily by small issuers, i.e., those with market capitalization of less than $\$ 50$ million. Underperformance, however, was not an IPO effect. Similar size and book-to-market firms that had not issued equity performed as poorly as IPOs in their sample. As small nonventure-backed IPOs are more likely to be held by individuals, investor sentiment plays a crucial role in their relative underperformance. These investors are more likely to be swayed by fads or lack of complete information. Venture-backed IPOs, on the other hand, have superior knowledge about the potential of startup firms they finance.

Barry, Muscarella, Peavy and Vetsuypens (1990), and Megginson and Weiss (1991) have found evidence that markets react favorably to the presence of venture capital financing at the time of an IPO. The latter researchers have also found that individuals, who are potentially more susceptible to fads and popular sentiments, hold a larger fraction of shares after the IPO for nonventure-backed firms. Also, venture capitalists stay on the board of directors long after the IPO and may continue to provide access to capital that nonventure-backed IPOs lack. Hoshi, Kashyap and Scharfstein (1991) have pointed out that because venture capitalists generally provide access to top-tier national investment and commercial bankers, they may partly overcome informational asymmetries that are associated with startup companies. Moreover, venture capitalists may have a hand in selecting management team that help the firm perform better in the long run.

More recently, Hellman and Puri (2002) have found that venture capital is related to a variety of professionalization measures, such as human resource policies, the adoption of stock option plans, and the hiring of a marketing VP. Venture-capital backed are also more likely and faster to replace the founder of the company with an outside CEO, both in situations that appear adversarial and those mutually agreed upon. Their evidence also suggests that venture capitalists play roles over and beyond those of traditional financial intermediaries.

The following are the principal data sources for our study:

- $\quad$ The IPO Reporter
- $\quad$ Investment Dealers' Digests
- $\quad$ www.Ipo.com
- $\quad$ www.yahoo.com
- $\quad$ www.hoovers.com
$\quad$ Compustat Data File




\subsection{Empirical Findings}

In Table 1, we have shown the total number of all IPOs and all venture-backed IPOs issued during 19902000. We find that out of the total of 4,566 IPOs, fully 1,672 or $36.62 \%$ of all IPOs were venture-backed.during this period.For all IPOs, they were issued in large number from 1992, reaching the maximun in 1996 when the number was 707, and 1993 coming next to it when 540 IPOs were issued. For the venture-backed IPOs, 1996 was also the best year when 233 IPOs of this nature were issued. The year 1998, however, was the lean year for the venturebacked IPOs which again took up stream in 1999 and 2000 when the numbers of all IPOs were still high, even when the stock market started to slacken off after March 2000.

Table 1

Numbers of Issues of All IPOs and Ventured - Backed IPOs, 1990 - 2000

\begin{tabular}{|c|c|c|}
\hline Year & All IPOs & Ven-Backed IPOs \\
\hline 1990 & 108 & 37 \\
\hline 1991 & 259 & 109 \\
\hline 1992 & 415 & 154 \\
\hline 1993 & 540 & 194 \\
\hline 1994 & 441 & 158 \\
\hline 1995 & 464 & 233 \\
\hline 1996 & 707 & 116 \\
\hline 1997 & 484 & 71 \\
\hline 1998 & 295 & 251 \\
\hline 1999 & 473 & 222 \\
\hline 2000 & 380 & \\
\hline
\end{tabular}

In Table 2, we have calculated for our sample of 237 IPO firms, the returns of different selected periods for venture-backed and nonventure-backed IPOs issued in the New York Stock Exchange (NYSE) between 1990 and 2001. Here we find that, except for the second-day return, the returns for all other periods were higher for the venture-backed IPOs as compared to the nonventure-backed IPOs. Although the difference in return between the two groups was slight for the first day, it was more pronounced for one-month, six-month, and one-year returns. It is interesting to note that the first-day return for both types of firms was the highest, falling precipitously for secondday and third-day returns. This indicates that in the short-run, IPOs were underpriced for both both the venturebacked and nonventure-backed firms. The one-year return for the nonventure-backed IPOs, although much lower in return than the venture-backed IPOs, showed modest gain as compared to the previous months.

Table 3 shows the returns of the same selected periods for the venture-backed and nonventure-backed IPOs issued in the Nasdaq stock market during 1990-2001. Her we also find that the returns of the venture-backed IPOs were higher than the nonventure-backed IPOs for all the time periods covered by our study. The first-day return of the venture-backed IPOs was almost double as compared to the nonventure-backed IPOs, while for the entire year it was almost triple as compared to the latter group. Also, the first-day returns for both groups were much higher for IPOs belonging to the Nasdaq stock market when compared with those belonging to the NYSE, which was also true for the one-year return. The technology-heavy Nasdaq market showed much higher returns where the majority of the IPOs were issued during 1990-2001. 
Table 2

NYSE Returns for Venture and Non Venture Backed IPOs 1990 - 2001

\begin{tabular}{|c|c|c|c|c|c|c|}
\hline & \multicolumn{3}{|c|}{ Venture } & \multicolumn{3}{|c|}{ Non Venture } \\
\hline & Mean & Median & $\begin{array}{l}\text { Standard } \\
\text { Deviation }\end{array}$ & Mean & Median & $\begin{array}{l}\text { Standard } \\
\text { Deviation }\end{array}$ \\
\hline & $n=76$ & $n=76$ & $n=76$ & $n=161$ & $n=161$ & $n=161$ \\
\hline First Day Return & $13.2 \%$ & $9.7 \%$ & $16.2 \%$ & $13.6 \%$ & $6.9 \%$ & $22.2 \%$ \\
\hline Second Day Return & $-0.4 \%$ & $-0.1 \%$ & $5.2 \%$ & $0.6 \%$ & $0.2 \%$ & $5.3 \%$ \\
\hline Third Day Return & $0.1 \%$ & $-0.5 \%$ & $6.7 \%$ & $0.4 \%$ & $0.1 \%$ & $6.8 \%$ \\
\hline One Month Return & $2.5 \%$ & $1.4 \%$ & $15.2 \%$ & $-1.0 \%$ & $-0.9 \%$ & $12.8 \%$ \\
\hline Six Month Return & $5.2 \%$ & $2.2 \%$ & $18.7 \%$ & $2.7 \%$ & $0.6 \%$ & $19.8 \%$ \\
\hline One Year Return & $10.3 \%$ & $7.5 \%$ & $22.6 \%$ & $6.3 \%$ & $-4.5 \%$ & $24.6 \%$ \\
\hline
\end{tabular}

Table 3

\section{Nasdaq Returns for Venture and Non Venture Backed IPOs 1990 - 2001}

\begin{tabular}{|c|c|c|c|c|c|c|}
\hline & \multicolumn{3}{|c|}{ Venture } & \multicolumn{3}{c|}{ Non Venture } \\
\hline & Mean & Median & $\begin{array}{c}\text { Standard } \\
\text { Deviation }\end{array}$ & Mean & Median & $\begin{array}{c}\text { Standard } \\
\text { Deviation }\end{array}$ \\
\cline { 2 - 7 } & $n=76$ & $n=76$ & $n=76$ & $n=133$ & $n=133$ & $n=133$ \\
\hline First Day Return & $65.27 \%$ & $38.40 \%$ & $77.32 \%$ & $35.86 \%$ & $24.20 \%$ & $65.56 \%$ \\
\hline Second Day Return & $-0.39 \%$ & $-2.44 \%$ & $10.05 \%$ & $-0.67 \%$ & $-0.59 \%$ & $9.07 \%$ \\
\hline Third Day Return & $-2.14 \%$ & $-3.20 \%$ & $12.40 \%$ & $-4.69 \%$ & $-2.99 \%$ & $12.37 \%$ \\
\hline One Month Return & $5.51 \%$ & $1.31 \%$ & $41.48 \%$ & $3.45 \%$ & $1.60 \%$ & $42.58 \%$ \\
\hline Six Month Return & $24.36 \%$ & $18.05 \%$ & $6.00 \%$ & $21.41 \%$ & $3.20 \%$ & $23.81 \%$ \\
\hline One Year Return & $39.16 \%$ & $26.80 \%$ & $25.23 \%$ & $14.59 \%$ & $9.41 \%$ & $58.02 \%$ \\
\hline
\end{tabular}

In Table 4, we have calculated the operating ratios as well as the growth of cash flows for these two types of IPOs issued in the New York Stock Exchange during 1991-2001. Here the results were mixed and we see no clear pattern for these two groups of IPOs. As for mean operating ratios, they were higher for the nonventurebacked IPOs in most of the years, while for the annual growth of cash flows, venture-backed IPOs did better in most of the years. It is interesting to note that in 1999 - the so-called 'bubble year' - growth of cash flows virtually exploded for both the groups. But here also, the growth of cash flows for the venture-backed IPOs was more than double as compared to the nonventure-backed IPOs.

In Table 5, we have shown the mean operating ratios and the growth of cash flows for these two types of IPOs issued in the Nasdaq stock market during 1994-2001. Here also, the result was mixed for the mean operating ratios as they were higher for the venture-backed IPOs in only four out of eight years. Similarly, the annual growth of cash flows was also higher in four out of eight years covered by our study. But the growth rate of cash flows started to go down in both 2000 and 2001 for both types of IPOs. It showed that the IPO market had cooled down during these years, as the mean operating ratios started to climb up --another sign of increased cost in running the operations during the later years. 
Table 4

Venture Backed vs. Non Venture Backed

Operating Ratios \& Growth of Cash Flows of the IPOs, 1991 - 2001, NYSE Firms

\begin{tabular}{|c|c|c|c|c|}
\hline \multirow{2}{*}{ Year } & \multicolumn{2}{|c|}{ Venture } & \multicolumn{2}{c|}{ Non Venture } \\
\cline { 2 - 5 } & $\begin{array}{c}\text { Mean Operating } \\
\text { Ratios }\end{array}$ & $\begin{array}{c}\text { Annual Growth of } \\
\text { Cash Flows(\%) }\end{array}$ & $\begin{array}{c}\text { Mean Operating } \\
\text { Ratios }\end{array}$ & $\begin{array}{c}\text { Annual Growth of } \\
\text { Cash Flows(\%) }\end{array}$ \\
\hline 1991 & 0.66 & 1.3 & 0.56 & 35.7 \\
\hline 1992 & 0.58 & 9.9 & 0.57 & 8.2 \\
\hline 1993 & 0.67 & 12.5 & 0.77 & 10.8 \\
\hline 1994 & 0.66 & 50.1 & 0.78 & 46.4 \\
\hline 1995 & 0.57 & 100.4 & 0.53 & 75.0 \\
\hline 1996 & 0.68 & 182.2 & 0.51 & 27.7 \\
\hline 1997 & 0.52 & 74.7 & 0.79 & 42.3 \\
\hline 1998 & 0.68 & 103.3 & 0.72 & 78.9 \\
\hline 1999 & 0.67 & 1843.3 & 0.69 & 785.4 \\
\hline 2000 & 0.58 & 467.0 & 0.67 & 368.0 \\
\hline 2001 & 0.56 & 144.3 & 0.66 & 126.5 \\
\hline
\end{tabular}

We have also employed the OLS regression model in order to explore the causal relationship between the IPO return as the dependent variable, and various relevant variables as the independent variables, for both the datasets of venture-backed IPOs and nonventure-backed IPOs. The multiple regression equation is of the form:

$\mathrm{AR}=\mathrm{a} 0+\mathrm{b} 1 \mathrm{FC}+\mathrm{b} 2 \mathrm{OP}+\mathrm{b} 3 \mathrm{SO}+\mathrm{b} 4 \mathrm{MC}$

Where:
$\mathrm{AR}=$ Returns of different periods;
$\mathrm{FC}=$ First-day closing price $(\$)$;
$\mathrm{SO}=$ Shares offered (million);
$\mathrm{MC}=$ Market capitalization ( $\$$ million)

Table 5

Venture vs. Non Venture

Operating Ratios \& Growth of the Cash Flows of the IPOs, 1994 - 2001 Nasdaq Firms

\begin{tabular}{|c|c|c|c|c|}
\hline \multirow{2}{*}{ Year } & \multicolumn{2}{|c|}{ Venture } & \multicolumn{2}{c|}{ Non Venture } \\
\cline { 2 - 5 } & $\begin{array}{c}\text { Mean Operating } \\
\text { Ratios }\end{array}$ & $\begin{array}{c}\text { Annual Growth of } \\
\text { Cash Flows }\end{array}$ & $\begin{array}{c}\text { Mean Operating } \\
\text { Ratios }\end{array}$ & $\begin{array}{c}\text { Annual Growth of } \\
\text { Cash Flows }\end{array}$ \\
\hline 1994 & 0.49 & 3.42 & 0.33 & -0.13 \\
\hline 1995 & 0.41 & 23.07 & 0.48 & 2.08 \\
\hline 1996 & 0.40 & 6.69 & 0.23 & 1.34 \\
\hline 1997 & 0.49 & 7.86 & 0.40 & 14.09 \\
\hline 1998 & 0.45 & 18.81 & 0.71 & 15.15 \\
\hline 1999 & 0.30 & 7.08 & 0.56 & 9.74 \\
\hline 2000 & 0.61 & -49.14 & 0.67 & -15.89 \\
\hline 2001 & 0.74 & -44.27 & 0.69 & -5.86 \\
\hline
\end{tabular}


In Table 6, we have shown the regression results for venture-backed IPOs listed in the New York

Stock Exchange (NYSE). We find that only the first-day closing price (FC) was negatively and significantly associated with the return variables in five out of six equations. Offer price (OP) was significant in two out of six equations, but the signs were contradictory. Shares Offered (SO) was significant only for the first-day return equation, as was Market capitalization (MC). Thus the significance of the FC variable indicates the underpricing of the IPOs, particularly on the first day when the IPOs were offered to the public for the first time.

In Table 7, we have shown the regression results for nonventure-based IPOs issued in the NYSE. Here we also find that the only the first-day closing price (FC) was negatively and consistently associated with the return variables in all the six equations. Offer price (OP) was negatively significant in first three of the six equations. Shares offered (SO) was significant (negatively) only for the one-year return equation as the dependent variable, as market capitalization (MC) was significant (positively) for the first-day return equation as the dependent variable. Both the R2 and F-ratios indicate the relevancy of the equations, following the methodology of OLS regression model.

Table 6

Multiple Regression Equations of Returns as the Dependent Variable (Ventured - Backed IPOs)

\begin{tabular}{|c|c|c|c|c|c|c|}
\hline \multirow{2}{*}{$\begin{array}{c}\text { Dependent } \\
\text { (Ars) }\end{array}$} & \multicolumn{6}{|c|}{ Independent Variable } \\
\hline & FC & OP & SO & MC & $\mathbf{R 2}$ & F Ratio \\
\hline $\begin{array}{c}\text { First Day } \\
\text { Return }(A R I)\end{array}$ & $\begin{array}{l}-3.044^{*} \\
(-7.477)\end{array}$ & $\begin{array}{l}-3.225 * \\
(-4.659)\end{array}$ & $\begin{array}{l}-0.349 * \\
(-1.953)\end{array}$ & $\begin{array}{l}0.751 * \\
(3.535)\end{array}$ & 0.450 & 5.962 \\
\hline $\begin{array}{c}\text { Second Day } \\
\text { Return }(A R 2)\end{array}$ & $\begin{array}{l}1.101 * * \\
(-1.369)\end{array}$ & $\begin{array}{l}1.398 * * \\
(1.500)\end{array}$ & $\begin{array}{c}0.173 \\
(0.230)\end{array}$ & $\begin{array}{c}-0.611 \\
(-0.683)\end{array}$ & 0.117 & 3.594 \\
\hline $\begin{array}{c}\text { Third Day } \\
\text { Return }(A R 3)\end{array}$ & $\begin{array}{l}-0.941 * \\
(-1.798)\end{array}$ & $\begin{array}{c}0.936 \\
(1.022)\end{array}$ & $\begin{array}{c}0.681 \\
(0.914)\end{array}$ & $\begin{array}{c}-0.848 \\
(-0.959)\end{array}$ & 0.138 & 3.722 \\
\hline $\begin{array}{c}\text { First Month } \\
\text { Return (AR4) }\end{array}$ & $\begin{array}{c}0.364 \\
(0.471) \\
\end{array}$ & $\begin{array}{c}-0.267 \\
(-0.274) \\
\end{array}$ & $\begin{array}{c}-0.009 \\
(-0.012)\end{array}$ & $\begin{array}{c}-0.032 \\
(-0.034)\end{array}$ & 0.223 & 4.105 \\
\hline $\begin{array}{c}\text { Six Month } \\
\text { Return (AR5) }\end{array}$ & $\begin{array}{l}-1.357^{*} \\
(-1.909)\end{array}$ & $\begin{array}{c}1.527 \\
(1.700)\end{array}$ & $\begin{array}{c}0.197 \\
(0.269)\end{array}$ & $\begin{array}{c}-0.544 \\
(-0.628)\end{array}$ & 0.271 & 4.927 \\
\hline $\begin{array}{c}\text { One Year Return } \\
\text { (AR6) }\end{array}$ & $\begin{array}{l}-0.521 * \\
(-2.683)\end{array}$ & $\begin{array}{c}0.646 \\
(0.671)\end{array}$ & $\begin{array}{c}-0.312 \\
(-0.398)\end{array}$ & $\begin{array}{c}0.012 \\
(0.013)\end{array}$ & 0.248 & 4.224 \\
\hline \multicolumn{7}{|c|}{$\begin{array}{l}\text { Standard Errors of the Independent Variables are in Percentages: } \\
* 1 \% \text { level of significance } \\
* * 5 \% \text { level of significance }\end{array}$} \\
\hline
\end{tabular}

\subsection{Conclusion}

We have found that, in general, the returns of the venture-based IPOs were higher than the nonventurebased IPOs. Also, the first-day returns of both these types of IPOs were higher than any other time periods, thus buttressing the findings of other researchers that IPOs of the United States had suffered from initial underpricing. As for operating ratios of these two groups as performance measure, the results were mixed and we have not detected any clear pattern in this regard. But the growth rates of cash flows were much higher for venture-backed IPOs than the nonventure-backed IPOs during 1990-2001. 
Table 7

Multiple Regression Equations of Annual Returns as the Dependent Variable ( Non Ventured - Backed IPOs)

\begin{tabular}{|c|c|c|c|c|c|c|}
\hline \multirow{2}{*}{$\begin{array}{c}\text { Dependent } \\
\text { (Ars) }\end{array}$} & \multicolumn{6}{|c|}{ Independent Variable } \\
\hline & FC & OP & SO & MC & $\mathbf{R 2}$ & F Ratio \\
\hline First-Day Return & $\begin{array}{c}-1.444^{*} \\
(8.776)\end{array}$ & $\begin{array}{l}-1.004 * \\
(-2.156)\end{array}$ & $\begin{array}{c}0.167 \\
(0.697)\end{array}$ & $\begin{array}{l}0.209 * \\
(1.813)\end{array}$ & 0.389 & 8.190 \\
\hline Second-Day Return & $\begin{array}{l}-0.843^{*} \\
(-4.629) \\
\end{array}$ & $\begin{array}{l}-0.845^{*} \\
(-4.306) \\
\end{array}$ & $\begin{array}{c}-0.108 \\
(0.190) \\
\end{array}$ & $\begin{array}{c}0.197 \\
(0.160) \\
\end{array}$ & 0.352 & 6.506 \\
\hline Third-Day Return & $\begin{array}{l}-0.788^{*} \\
(-4.405) \\
\end{array}$ & $\begin{array}{l}-0.690^{*} \\
(-3.338) \\
\end{array}$ & $\begin{array}{c}0.090 \\
(0.150) \\
\end{array}$ & $\begin{array}{c}-0.144 \\
(0.225) \\
\end{array}$ & 0.281 & 4.687 \\
\hline First Month Return & $\begin{array}{l}0.197 * * \\
(-1.682)\end{array}$ & $\begin{array}{c}-0.013 \\
(-0.045)\end{array}$ & $\begin{array}{c}-0.136 \\
(-0.196)\end{array}$ & $\begin{array}{c}0.205 \\
(0.785)\end{array}$ & 0.301 & 3.370 \\
\hline Six Month Return & $\begin{array}{l}0.237 * * \\
(-1.358)\end{array}$ & $\begin{array}{c}0.150 \\
(0.622)\end{array}$ & $\begin{array}{l}-0.135 \\
(0.193)\end{array}$ & $\begin{array}{c}0.147 \\
(0.196)\end{array}$ & 0.239 & 3.281 \\
\hline One Year Return & $\begin{array}{l}-0.458^{*} \\
(-2.178)\end{array}$ & $\begin{array}{c}-0.034 \\
(-0.149)\end{array}$ & $\begin{array}{c}-1.097 * * \\
(-1.674)\end{array}$ & $\begin{array}{c}1.233 \\
(1.755)\end{array}$ & 0.236 & 3.894 \\
\hline
\end{tabular}

When we run the regression equations to gauge the causal relationship between return statistic as dependent variable and other relevant variables as independent variables, we find that only the first-day closing price was significantly and negatively associated with most return variables. Both market capitalization and offer price as explanatory variables were significant only in a very limited number of equations, while number of shares as explanatory variable was not significant at all in most equations. Our results thus confirm the conclusion reached by Brav and Gompers that venture-backed IPOs performed better than nonventure-backed IPOs during the period covered by our study (1990-2001).

\section{Bibliography}

1. Barry, C., C. Muscaralla, J. Peavy, and M. Vetsuypens, 1990, "The Role of Venture Capital in the Creation of Public Companies: Evidence from the Going-Public Process," Journal of Financial Economics, 27, 447476.

2. Brav, A. and P.A. Gompers, 1997, "Myth or Reality? The Long-Run Underperformance of Initial Public Offerings: Evidence from Venture and Nonventure Capital-Based Companies," Journal of Finance, 52, 1791-1821.

3. Fama, E., and K. French, 1993, "Common Risk Factors in the Returns of Stocks and Bonds," Journal of Financial Economics, 33, 3-55.

4. Ghosh, Arvin, 2003, "Post-Issue Operating Performance of Nasdaq IPOs," Journal of Business and Economic Research, 1, 37-42.

5. Hellman, T., and M. Puri, 2002, "Venture Capital and the Performance of Start-Up Firms: Empirical Evidence," Journal of Finance, 58, 169-197.

6. Hoshi, T., A. Kashyap, and D. Scharfstein, 1991, "Corporate Structure, Liquidity, and Investment," Quarterly Journal of Economics, 106, 33-60.

7. Loughran, T., and J. R. Ritter, 1995, "The New Issue Puzzle," Journal of Finance, 50, 165-199.

8. Megginson, W., and K. Weiss, 1991, "'Venture Capitalist Certification in Initial Public Offerings," Journal of Finance, 46, 879-903.

9. Ritter, J. R., 1991, "The Long-Run Performance of Initial Public Offerings," Journal of Finance, 46, 3-27.

10. Ritter, J. R., and I. Welch, 2002, "A Review of IPO Activity, Pricing, and Allocations," Journal of Finance, 57, 1795-1828. 
Notes 